\title{
Crustacean and mollusk species diversity and abundance in the mangrove communities of Mimika District, Papua, Indonesia
}

\author{
GESANG SETYADI ${ }^{1, \bullet}$, DWI LISTYO RAHAYU ${ }^{2}$, RUDHI PRIBADI ${ }^{3}$, RETNO HARTATI $^{3}$, \\ DIAH PERMATA WIJAYANTI ${ }^{3}$, DENNY NUGROHO SUGIANTO ${ }^{4}$, AGUNG DARMAWAN ${ }^{5}$ \\ ${ }^{1}$ Doctorate Program in Marine Science, Faculty of Fisheries and Marine Sciences, Diponegoro University. Jl. Prof. Soedarto, Tembalang, Semarang \\ 50725, Central Java, Indonesia. Tel./fax.: +62-298-7474698, •email: gesang.setyadi@ gmail.com \\ ${ }^{2}$ Center for Marine Bio Industry, Indonesian Institute of Sciences. Telukode, Pemenang Barat, North Lombok 83352, West Nusa Tenggara, Indonesia \\ ${ }^{3}$ Department of Marine Science, Faculty of Fisheries and Marine Sciences, Universitas Diponegoro. Jl. Prof. Soedarto, Tembalang, Semarang 50725, \\ Central Java, Indonesia \\ ${ }^{4}$ Department of Oceanography, Faculty of Fisheries and Marine Sciences, Universitas Diponegoro. Jl. Prof. Soedarto, Tembalang, Semarang 50725, \\ Central Java, Indonesia \\ ${ }^{5}$ Environmental Department, PT Freeport Indonesia. J1. Mandala Raya Selatan No. 1, Kuala Kencana, Mimika 99968, Papua, Indonesia
}

Manuscript received: 5 August 2021. Revision accepted: 11 September 2021.

\begin{abstract}
Setyadi G, Rahayu DL, Pribadi R, Hartati R, Wijayanti DP, Sugianto DN, Darmawan A. 2021. Crustacean and mollusk species diversity and abundance in the mangrove communities of Mimika District, Papua, Indonesia. Biodiversitas 22: 4146-4157. A mangrove crustacean and mollusk species diversity study was carried out in four mangrove estuaries in Mimika District, Papua, Indonesia. Two locations were selected on each estuary; for each location, samples of crustaceans and mollusks were collected from $5 \mathrm{~m}$ $\times 5 \mathrm{~m}$ plots, and mangrove trees were recorded on $10 \mathrm{~m} \times 10 \mathrm{~m}$ plots at a distance of $10 \mathrm{~m}, 250 \mathrm{~m}$ and $500 \mathrm{~m}$ perpendicular to the riverbank. This study recorded a total of 41 species of crustaceans and 32 species of mollusks the latter comprising three species of bivalves and 29 gastropod species. The number of crab species found was among the highest compared to similar studies in the world. The average number of species collected from each $25 \mathrm{~m}^{2}$ plot was $7.6 \pm 4.2$ species for crustaceans, with an average abundance of $87 \pm$ 3.5 individuals; for mollusks, it was $3.3 \pm 3$ species with an average abundance of $28 \pm 48.4$. Crustacean abundance and species composition were influenced by inundation frequency. There was a strong correlation between the crab Parasesarma cricotum and the association of Rhizophora apiculata and Bruguiera gymnorrhiza mangroves, and Clistocoeloma amamaparense and the association of B. gymnorrhiza, R. apiculata, and Bruguiera parviflora mangroves. For mollusks, correlations were found between Terebralia palustris and Ellobium aurisjudae and the association of $R$. apiculata and B. parviflora mangroves. The highest crustacean Shannon-Wiener diversity index was associated with Sonneratia alba and Avicennia marina mangroves, and the highest mollusk Shannon-Wiener diversity index was associated with $R$. apiculata and B. gymnorrhiza mangroves.
\end{abstract}

Keywords: Crustacean, diversity, mangrove, Mimika, mollusks, Papua

\section{INTRODUCTION}

Mangroves are highly productive coastal ecosystems with significant ecological and environmental value, providing habitats and nutrients for aquatic fauna and soil stabilization (El-Regal et al. 2014; Hogarth 2015). Mangrove vegetation contributes to faunal biodiversity (Ashton et al. 2003a; Colpo et al. 2011).

Mangrove forests are populated by a variety of macroinvertebrates, such as brachyuran crabs, hermit crabs, gastropods, and bivalves. The most abundant, and the greatest biomass, is crustaceans, particularly true crabs (Hogarth 2015), which have various ecological roles and functions in the mangrove ecosystem and play a major role in the energy flow by exporting mangrove litter (NgoMassou et al. 2018). Crab burrows also allow seawater to penetrate and aerate the sediment and exchange nutrients (Ashton et al. 2003 ). Worldwide, more than 300 species of brachyuran crabs have been recorded in mangroves (Ravichandran et al. 2011). While there is limited information on brachyuran crabs in Indonesia, research in Peninsular and East Malaysia has found more than one hundred brachyuran species inhabiting mangrove ecosystems (Tan and Ng 1994).

Mollusks typically snails comprise another dominant group in mangroves. Their distributions are affected by the extent of tidal exposure, substrate type, salinity and light intensity (Nagelkerken et al. 2008). The other group is bivalves (clams), which have high biomass and abundance. However, mangroves represent a harsh environment for bivalves due to the limited filter-feeding activity, while the distribution of their planktonic larvae is hampered by a lack of inundation (Zvonareva et al. 2009). 277 gastropod species have been recorded in mangrove ecosystems worldwide (Cantera et al. 1983), with the number of bivalves found in Indo-Pacific mangroves totaling 86 species (Morton 1983).

Papua is the eastern-most province in Indonesia and has one of the largest mangrove forests in the world. The total mangrove forest in Papua, Indonesia, was recently recorded at 1,497,724 hectares, or around $46 \%$ of the total mangrove forest in Indonesia, comprising 3.3 million ha (Setyadi et al. 2021). The majority of mangroves in Papua are found on the southern coast of Papua Island, including Mimika 
district. All estuaries in Mimika District have mangroves, with an estimated area of 186,291 ha (Aslan et al. 2018), making it one of the least disturbed mangrove forests in Indonesia; nevertheless, there have been limited studies and international publications on this. Such a gap in the research represents an opportunity to explore the biodiversity of crabs and mollusks and to assess the correlation between the mangrove macro-invertebrate biodiversity and the mangrove community.

The main objective of this study is to determine the diversity, abundance and community structures of crustacean and mollusk macrofauna in the Mimika District of Papua, Indonesia. The other objective is to describe the correlation between crustacean and mollusk diversity and mangrove vegetation association as well as examine environmental factors such as inundation.

\section{MATERIAL AND METHODS}

\section{Study area}

The study was carried out from March to May, 2019, in four estuaries in the Mimika District, Papua Province, Indonesia. Papua Province is the eastern-most province in
Indonesia, located in Western New Guinea. Mimika District has the highest mountain on the Australia plate, with its highest peak at $3750 \mathrm{~m}$. The Mimika coastal plains are characterized by extensive swampy areas spreading from the coast in a northeasterly direction, with mountains rising abruptly from the edge of the plains. The vast mangrove forests extend about $20 \mathrm{~km}$ inland, and have developed from the high sedimentation resulting from the combination of high rainfall of 4-13 $\mathrm{m} \mathrm{yr}^{-1}$, erosion from the rugged mountains, and 3.3 to 3.6 tidal ranges (Setyadi et al. 2009; Aslan et al. 2018).

The four estuaries were selected for the studies were the Kamora, Tipuka, Ajkwa and Minajerwi estuaries, whereby two sampling locations were selected for each estuary. These are shown in Figure 1, with detailed coordinates shown in Table 1. Kamora estuary has the highest catchment area of $1475 \mathrm{~km}^{2}$ and an average river flow of $417 \mathrm{~m}^{3} \mathrm{~s}^{-1}$. Tipuka has a catchment area of $178 \mathrm{~km}^{2}$ and an average river flow of $41 \mathrm{~m}^{3} \mathrm{~s}^{-1}$. Ajkwa has a catchment area of $270 \mathrm{~km}^{2}$ and an average river flow of $115100 \mathrm{~m}^{3} \mathrm{~s}^{-1}$, and Minajerwi has a catchment area of 844 $\mathrm{km}^{2}$ and an average river flow of $100 \mathrm{~m}^{3} \mathrm{~s}^{-1}$ (PT Puri Fajar Mandiri 2002).

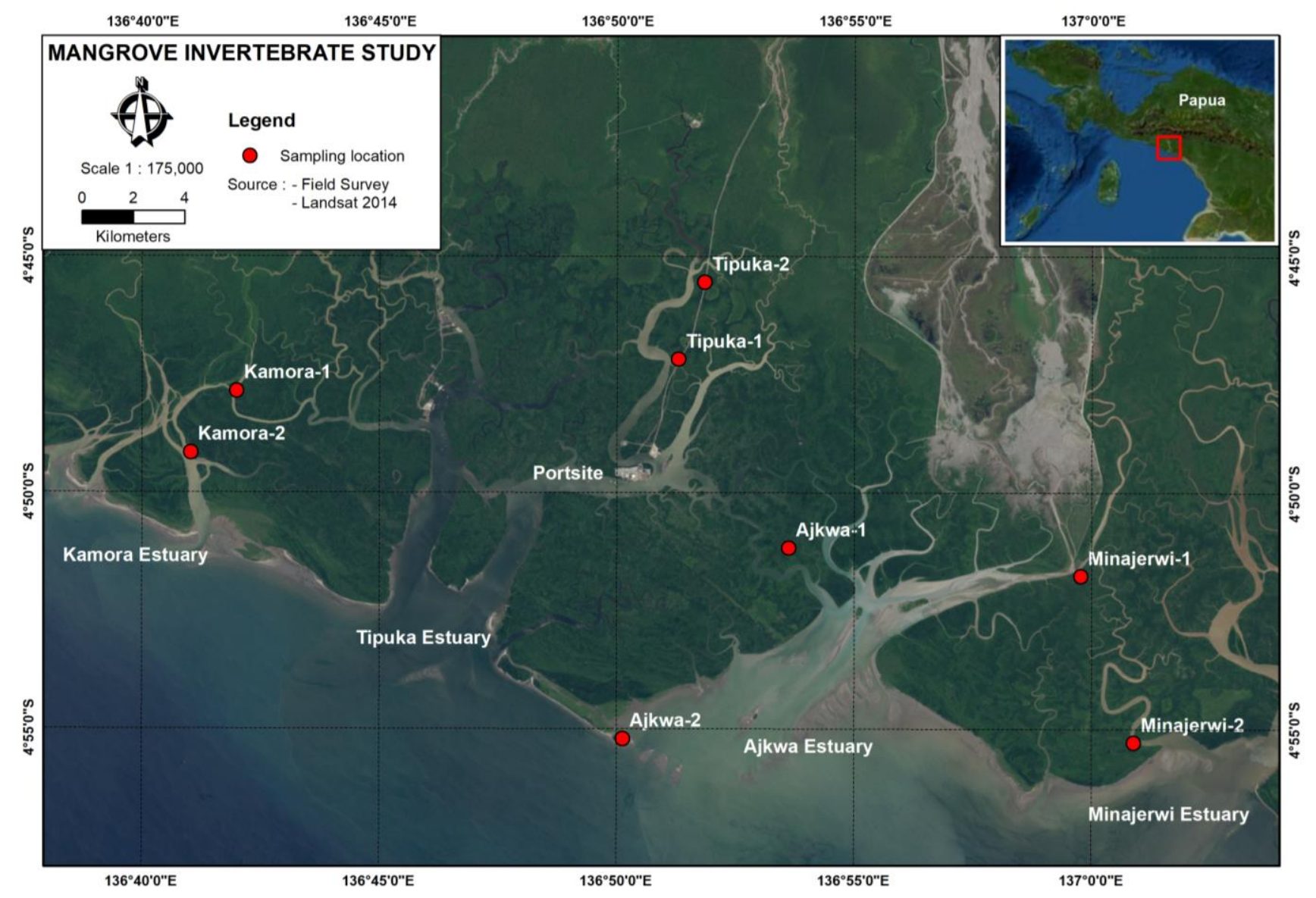

Figure 1. Study locations in Mimika District, Papua Province, Indonesia 


\section{Data collection}

At each location, transects were established at distances of $10 \mathrm{~m}, 250 \mathrm{~m}$ and $500 \mathrm{~m}$ inland from the riverbank in the intertidal of the mangrove forest. At each distance, a $10 \mathrm{~m}$ $\mathrm{x} 10 \mathrm{~m}$ quadrat and three replicates were established, then the mangrove tree species, including the number for each species, were recorded. At each distance, crustaceans and mollusks were collected within $5 \mathrm{~m}$ x $5 \mathrm{~m}$ quadrats, with a total of three quadrats per location. The method was adopted from Ngo-Masou et al. (2018), but with larger quadrats. Sampling was carried out during the daytime at low tide. The collection process involved three people and included excavating burrows and removing all crabs and mollusks seen within each quadrat within the transect for about one hour until no more crabs or mollusks were visible. Hand trowels were used to excavate the crabs and bivalves from 10-20 cm deep burrows. All samples were put into labelled plastic bags and put in a cooler box with ice for transport to the laboratory. In the laboratory, mud was removed from all the specimens, and each specimen was preserved in a 70-75\% solution of ethanol for later species identification. The identification of the crustaceans referred to Rahayu and Davie (2002; 2006), Rahayu and Takeda (2000), Rahayu and Setyadi (2009) and Li et al. (2018), whereas the identification of the mollusks referred to Carpenter and Niem (1998) and Setyadi et al. (2009).

The field parameters collected for each sampling plot were GPS coordinates, water temperature, salinity, and dissolved oxygen. Water parameters were collected from all ponding water and burrowing water found in the plot area.

\section{Data analysis}

For the mangrove tree data, the total number of species, density, and Shannon-Wiener index ( $\left.\mathrm{H}^{\prime}\right)$ and evenness (J') were calculated. The Shannon-Wiener index is commonly used to evaluate the diversity of mangrove species in Indonesia (Kasim et al. 2018; Sadono et al. 2020). Using PRIMER (2016), seven indices were calculated for crustaceans and mollusks: abundance, species richness (Margalef), Pielou's evenness, Shannon diversity, Simpson's dominance, Simpson's diversity and Simpson's dominance.

The Bray-Curtis similarity was calculated for the crustaceans and mollusk data, using the PRIMER software to determine the similarity between the sampling locations and between the plots. The relationships between the crustacean and mollusk species and the mangrove community types were analyzed using PCA (Principal Component Analysis) with PAST (Paleontological Statistics Software).

\section{RESULTS AND DISCUSSIONS}

\section{Field parameters}

The parameters measured in the field are shown on Table 1. The data show that the water temperature at all sampling locations ranged from 25.7 to $30.5{ }^{\circ} \mathrm{C}$, salinity ranged from 0.28 to $25.7 \%$, $\mathrm{pH}$ ranged from 6.34 to 7.75 , and dissolved oxygen ranged from 0.4 to $8.2 \mathrm{mg} / \mathrm{L}$.

\section{Mangrove trees}

The species of mangrove trees from the eight locations are shown in Table 2. A total of 13 mangrove tree species were observed. The highest number of species (8) was found at Ajkwa-2. The most dominant mangrove tree species in all locations were Rhizophora apiculata and Bruguiera gymnorrhiza. Avicennia marina was only dominant at Ajkwa-2, which is located in the seaward zone of the high tidal area.

The lowest density was at Kamora-2 and the highest was at Ajkwa-2. The highest Shannon-Wiener index ( $\left.\mathrm{H}^{\prime}\right)$ was at Ajkwa-1 and the lowest was at Kamora-2, whereas the highest evenness (J') was at Ajkwa-1 and the lowest was at Minajerwi-2.

\section{Species richness}

A total of 41 species of crustacean and 32 species of mollusk were found in the study area (Table 1). The mollusks comprised three species of bivalves and 29 gastropods. The crab species recorded with the highest total abundance from all the plots was Parasesarma indiarum (785), followed by Parasesarma cricotum (280), Sarmatium germaini (232), Clistocoeloma amamaparense (215) and Sesarmoides borneensis (107). For mollusks, the highest total abundance from all the plots was found for Ellobium aurisjudae (193) and Terebralia palustris (140).

The average number of species collected from each 25 $\mathrm{m}^{2}$ plot for crustaceans was $7.6 \pm 4.2$ species and the average abundance was $87 \pm 3.5$ individuals. The highest species number recorded was from Ajkwa-2 at $250 \mathrm{~m}$ (16 species). Other high species numbers for collected crustaceans were found at Ajkwa-2 at $10 \mathrm{~m}$ (14 species), Kamora-1 at 10 m (14 species), and Kamora-1 at 500 m (14 species). The greatest abundance of collected crustaceans was at Ajkwa-2 at $10 \mathrm{~m}$ (251 individuals), followed by Ajkwa-2 at $500 \mathrm{~m}$ (243 individuals), Ajkwa-2 at $250 \mathrm{~m}$ (235 individuals), Kamora-1 at $500 \mathrm{~m}$ (223 individuals), and Kamora-1 at $10 \mathrm{~m}$ (144 individuals).

Table 1. Coordinates and field parameters taken from the sampling locations in Mimika District, Papua, Indonesia

\begin{tabular}{|c|c|c|c|c|c|c|}
\hline \multirow{2}{*}{ Location } & \multicolumn{2}{|c|}{ Coordinates } & \multirow{2}{*}{ Temp $\left({ }^{\circ} \mathrm{C}\right)$} & \multirow{2}{*}{ Salinity (\%o) } & \multirow{2}{*}{ pH } & \multirow{2}{*}{ DO } \\
\hline & South & East & & & & \\
\hline Kamora 1 & $04^{0} 51^{\prime} 10,20^{\prime \prime}$ & $136^{0} 53^{\prime} 36,82^{\prime \prime}$ & $29.00 \pm 0.44$ & $7.63 \pm 3.12$ & $7.26 \pm 0.02$ & $2.40 \pm 0.78$ \\
\hline Kamora 2 & $04^{0} 51^{\prime} 45,63^{\prime \prime}$ & $136^{0} 59^{\prime} 46,14^{\prime \prime}$ & $28.53 \pm 0.15$ & $9.97 \pm 1.42$ & $6.55 \pm 0.18$ & $3.90 \pm 2.00$ \\
\hline Tipuka 1 & $04^{\circ} 55^{\prime} 12.08^{\prime \prime}$ & $136^{\circ} 50^{\prime} 07.34^{\prime \prime}$ & $29.30 \pm 1.15$ & $3.82 \pm 0.87$ & $7.32 \pm 0.07$ & $6.83 \pm 0.50$ \\
\hline Tipuka 2 & $04^{0} 55^{\prime} 17,18^{\prime \prime}$ & $137^{\circ} 00^{\prime} 53,36^{\prime \prime}$ & $28.87 \pm 0.25$ & $6.23 \pm 0.92$ & $7.19 \pm 0.09$ & $6.90 \pm 0.17$ \\
\hline Ajkwa 1 & $04^{\circ} 47^{\prime} 50,90^{\prime \prime}$ & $136^{0} 41^{\prime} 58,92^{\prime \prime}$ & $28.90 \pm 0.40$ & $11.60 \pm 0.90$ & $7.19 \pm 0.02$ & $7.20 \pm 1.40$ \\
\hline Ajkwa 2 & $04^{\circ} 49^{\prime} 09,17^{\prime \prime}$ & $136^{\circ} 41^{\prime} 01,17^{\prime \prime}$ & $26.70 \pm 0.95$ & $19.61 \pm 5.41$ & $7.56 \pm 0.08$ & $6.07 \pm 0.35$ \\
\hline Minajerwi 1 & $04^{0} 47^{\prime} 10,66^{\prime \prime}$ & $136^{0} 51^{\prime} 17,21^{\prime \prime}$ & $27.73 \pm 0.57$ & $0.43 \pm 0.17$ & $7.55 \pm 0.17$ & $6.60 \pm 0.35$ \\
\hline Minajerwi 2 & $04^{\circ} 45^{\prime} 32,67^{\prime \prime}$ & $136^{0} 51^{\prime} 50,20^{\prime \prime}$ & $27.10 \pm 0.61$ & $13.37 \pm 1.96$ & $7.26 \pm 0.01$ & $1.13 \pm 0.64$ \\
\hline
\end{tabular}


Tabel 2. Vegetation data of Mimika District, Papua, Indonesia

\begin{tabular}{llcccc}
\hline \multicolumn{1}{c}{ Location } & \multicolumn{1}{c}{ Mangrove Species } & S & D & H' & J' \\
\hline Kamora-1 & Ra, Bg, Rm, Bp & 4 & $722 \pm 96$ & $0.82 \pm 0.16$ & $0.86 \pm 0.10$ \\
Kamora-2 & Ra, Bp, Bg, Xg & 4 & $666 \pm 235$ & $0.66 \pm 0.15$ & $0.70 \pm 0.16$ \\
Tipuka-1 & Ra, Xg, Bp, Bg & 4 & $711 \pm 107$ & $1.07 \pm 0.36$ & $0.81 \pm 0.19$ \\
Tipuka-2 & Bg, Ra, Xg, Cs, Xm & 5 & $878 \pm 204$ & $0.76 \pm 0.52$ & $0.49 \pm 0.24$ \\
Ajkwa-1 & Ra, Bg, Cs, Bp & 4 & $767 \pm 88$ & $1.19 \pm 0.14$ & $0.92 \pm 0.06$ \\
Ajkwa-2 & Am, Bp, Sa, Ra, Ll, Ea, Nf, Bg & 8 & $1089 \pm 414$ & $1.12 \pm 0.47$ & $0.80 \pm 0.05$ \\
Minajerwi-1 & Ra, Bg, Nf, Xg, Bp, Ba & 6 & $944 \pm 171$ & $1.05 \pm 0.09$ & $0.83 \pm 0.16$ \\
Minajerwi-2 & Bg, Ra, Bp, Cs & 4 & $756 \pm 301$ & $0.62 \pm 0.09$ & $0.47 \pm 0.29$ \\
\hline
\end{tabular}

Note: S: Species Number; D: Density (tree ha $\left.{ }^{-1}\right)$; H': Shannon-Weinner Index; J': Evenness Index; Ra: Rhizophora apiculata; Bg: Bruguiera gymnorrhiza; Rm: Rhizophora mucronata; Bp: Bruguiera parviflora; Xg: Xylocarpus granatum; Cs: Camptostemon schultzii; Xm: Xylocarpus moluccensis; Am: Avicennia marina; Sa: Sonneratia alba; Ll: Lumnitzera littorea; Ea: Excoecaria agallocha; Nf: Nypa fruticans; Ba: Barringtonia asiatica

Mollusks collected from each $25 \mathrm{~m}^{2}$ plot had an average of $3.3 \pm 3$ species with an average abundance of $28 \pm 48.4$. The highest species number recorded was from Minajerwi1 at $250 \mathrm{~m}$ (11 species). Other high species numbers for collected mollusks were found at Minajerwi-1 at $10 \mathrm{~m}(9$ species), Minaerwi-1 at $500 \mathrm{~m}$ (7 species), Ajkwa-2 at 10 $\mathrm{m}$ (7 species). The highest abundance of collected mollusks was at Ajkwa-2 at $10 \mathrm{~m}$ (179 individuals), followed by Ajkwa-2 at $250 \mathrm{~m}$ (158 individuals), Minajerwi-1 at $250 \mathrm{~m}$ (86 individuals), and Minajerwi-1 at $10 \mathrm{~m}$ (44 individuals).

The mollusk species recorded with the highest total abundance at all the plots were Polymesoda expansa (15 individuals) and Isognomon ephippium (13 individuals). For gastropods, the highest total abundance was Ellobium aurisjudae (193 individuals), followed by Terebralia palustris (140 individuals) and Neritina violacea (72 individuals). The most common species was Nerita balteata (found in 10 plots), followed by E. aurisjudae, $N$. planospira, and $N$. violacea, which were recorded in 6 plots each. There were 11 species of mollusk that found in one plot and 7 plots had no mollusk species.

The mean of species number, number of individuals, species richness, Shannon diversity index, evenness, and Simpson's dominance can be seen in Table 4. The highest species richness and Shannon diversity index for crustaceans was at Kamora-1 (2.46 \pm 0.07 and $1.68 \pm 0.13$ respectively) and the lowest was Ajkwa-1 (0.80 \pm 0.04 and $0.95 \pm 0.48$, respectively). For mollusks, the highest species richness and Shannon diversity index were at Minajerwi-1 (1.93 \pm 0.13 and $1.62 \pm 0.42$, respectively).

The highest evenness index for crustaceans was found at Minajerwi-1 $(0.94 \pm 0.04)$, which is classified as high (Krebs 1989), and the lowest was at Ajkwa-2 (0.57 \pm 0.12$)$, which is classified as medium. The highest Shannon dominancy was found at Tipuka-2 $(0.55 \pm 0.34)$ and the lowest was at Minajerwi-2 $(0.31 \pm 0.06)$. For mollusks, the highest evenness index was at Kamora-1 $(0.86 \pm 0.12)$, which is classified as high. The highest Shannon dominancy was at Ajkwa-1 $(0.67 \pm 0.22)$.

\section{Similarity}

The Bray-Curtis similarity among the sampling locations was calculated using PRIMER. The Bray-Curtis analysis, which is based on the similarity percentage of abundance for mangrove species, is shown on Figure 2. Based on the analysis, the mangroves from the study locations can be grouped into eight clusters: A. Association of $S$. alba and A. marina (Ajkwa-2B); B. Association of A. marina, S. alba, B. parviflora and R. apiculata (Ajkwa-2A and Ajkwa-2C); C. Association of $R$. apiculata, $B$. gymnorrhiza and $X$. granatum (Minajerwi-1C and Tipuka 2C); D. Association of $R$. apiculata and B. parviflora (Kamora-1A, Tipuka-1B, Tipuka-1C, Tipuka-1A, Kamora2A, and Kamora-2B), E. Association of B. gymnorrhiza and $R$. apiculata (Minajerwi-2C and Tipuka-2A); F. Association of B. gymnorrhiza, R. apiculata, B. parviflora, and C. schultzii (Minajerwi-2B and Tipuka-2B); G. Association of $R$. apiculate, B. gymnorrhiza and $C$. schultzii (Ajkwa-1A and Ajkwa-1B); H. Association of $R$. apiculata and B. gymnorrhiza (Kamora-2C, Minajerwi-1B, Kamora-1C, Minajerwi-2A, Ajkwa-1C, Kamora-1B, and Minajerwi-1A).

The Bray-Curtis similarity analysis for the crustaceans at all sampling locations can be seen in Figure 3. Meanwhile, Figure 4 shows the analysis based on plot.

Based on the Bray-Curtis similarity analysis for crustaceans from all sampling locations, Ajkwa-2, Minajerwi-2 and Kamora-2 were in one group. This shows that crustacean abundance and species composition are influenced by proximity to the coastline since these three locations are close to the coastline and thus experience more frequent inundation. The most similar locations were Tipuka-1 and Tipuka-2 (67.56\%). Other locations that had a similarity of more than $60 \%$ were Tipuka- 2 and Ajkwa-1 (63.47\%) and Tipuka-1 and Ajkwa-1 (61.96\%). The most distinct locations were Ajkwa-2 and Minajerwi-1 (21.22\%).

Based on plot, the most distinct locations were Minajerwi-1B and Minajerwi 2C. Other sampling plots can be grouped into three clusters with a similarity of $40 \%$. Only two species of crabs were found in Minajerwi-1B, namely Episesarma lafondi and Neosarmatium papuense, whereas only Parasesarma leptosome, Sarmatium germaini and Sesarmoides borneensis were found in Minajerwi-2C.

The Bray-Curtis similarity analysis for the mollusks from all sampling locations can be seen in Figure 5, while Figure 6 shows the analysis based on plot. 
Table 3. Crustacean and Mollusk collected from the sampling location in Mimika District, Papua, Indonesia

\begin{tabular}{|c|c|c|c|c|c|c|c|c|c|c|c|c|c|c|c|c|c|c|c|c|c|c|c|c|c|}
\hline & \multicolumn{3}{|c|}{ Kamora-1 } & \multicolumn{3}{|c|}{ Kamora-2 } & \multicolumn{3}{|c|}{ Tipuka-1 } & \multicolumn{3}{|c|}{ Tipuka-2 } & \multicolumn{3}{|c|}{ Ajkwa-1 } & \multicolumn{3}{|c|}{ Ajkwa-2 } & \multicolumn{3}{|c|}{ Minajerwi-1 } & \multicolumn{3}{|c|}{ Minajerwi-2 } & \multirow[t]{2}{*}{ Total } \\
\hline & $\mathbf{A}$ & B & $\mathbf{C}$ & $\mathbf{A}$ & $\mathbf{B}$ & $\mathbf{C}$ & $\mathbf{A}$ & B & $\mathbf{C}$ & $\mathbf{A}$ & B & $\mathbf{C}$ & $\mathbf{A}$ & $\mathbf{B}$ & $\mathbf{C}$ & $\mathbf{A}$ & $\mathbf{B}$ & $\mathbf{C}$ & $\mathbf{A}$ & B & $\mathbf{C}$ & $\mathbf{A}$ & B & $\mathbf{C}$ & \\
\hline Crustacean & & & & & & & & & & & & & & & & & & & & & & & & & \\
\hline Alpheus euphrosyne & 39 & 9 & 4 & & & & & 1 & 11 & 1 & & & & 3 & 1 & & 3 & & & & & 1 & & & 73 \\
\hline Alpheus sp. B & 1 & & & & & & & & & & & & & & & 1 & & 4 & & & & & & & 6 \\
\hline Caridina sp. & 1 & & & & & & & & 3 & & & & & & & & 1 & & & & & & & & 5 \\
\hline Clibanarius longitarsus & & & & & & & & & & & & & & & & 6 & 4 & 1 & & & & & & & 11 \\
\hline Clistocoeloma amamaparense & 8 & 15 & 23 & 1 & 1 & 13 & 7 & 1 & 1 & 4 & 1 & 18 & 6 & & 5 & 12 & 2 & 14 & 8 & & 2 & 5 & 68 & & 215 \\
\hline Corophium sp. & & & & & & & & & & & & & & & & 4 & & & & & & & & & 4 \\
\hline Episesarma lafondi & & & & & & & & & & & & & & & & & & & & 1 & & & 1 & & 2 \\
\hline Epixanthus dentatus & & & & & & 1 & & & & 1 & & & & & & & & & & & & & & & 2 \\
\hline Haberma kamora & & & 2 & & & & 5 & & & 5 & & & & & & & & & 3 & & 2 & & & & 17 \\
\hline Helice sp. & & & & & & & 2 & & 1 & & & & & & & & & & & & & & & & 3 \\
\hline Heteropanope longipedes & & & & & & 4 & & & & & & & & & & & 1 & & & & & 1 & & & 6 \\
\hline Ilyograpsus paludicola & 1 & & & & & & & & & & & & & & & 1 & & & & & & & & & 2 \\
\hline Ilyoplax dentatus & & & & & & & & & & & & & & & & & 1 & & & & & & & & 1 \\
\hline Labuanium politum & & & 1 & & & & & & & & & & & & & & & & & & & & & & 1 \\
\hline Macrobrachium sp. & & & & & & & & & 3 & & & & & & & & & & & & & & & & 3 \\
\hline Macrophthalmus pacificus & 1 & 1 & & & & & & & & & & & & & & & 1 & & & & & & & & 3 \\
\hline Metapenaeus ensis & 2 & & & & & & & & & & & & & & & & & & & & & & & & 2 \\
\hline Mictyris sp. & & & & & & & & & & & & & & & & 28 & 25 & & & & & & & & 53 \\
\hline Nanosesarma edamensis & & & & & & & & & & & & & 4 & & & & & & & & & & & & 4 \\
\hline Neosarmatium bidentatum & & & & & & & & & & & & & & & & 1 & & & 4 & & & & & & 5 \\
\hline Neosarmatium papuense & & & 1 & & & & & & & & & & & & & & & & & 2 & 2 & & & & 5 \\
\hline Neosarmatium rotundifrons & & & 8 & & & & & & & & & & & & & & & & & & & & & & 8 \\
\hline Paracleistostoma quadratum & 2 & 1 & & & & & & & & & & & & & & & 1 & & & & & & & & 4 \\
\hline Parasesarma charis & & & 4 & & & & & & & & & & & & & & & & & & & & 1 & & 5 \\
\hline Parasesarma cricotum & 47 & 40 & 134 & & & & 32 & 15 & 1 & 8 & & & & & & & & & & & 3 & & & & 280 \\
\hline Parasesarma indiarum & 31 & 24 & 17 & 8 & 15 & 27 & 2 & 24 & 32 & 8 & 17 & 48 & 22 & 10 & 9 & 145 & 63 & 179 & 6 & & & 44 & 54 & & 785 \\
\hline Parasesarma gracilipes & & & & & & & & & & & & & & & & 26 & 3 & 3 & & & & 1 & 1 & 4 & 38 \\
\hline Parasesarma rutilimanum & & 1 & 8 & 1 & & 3 & 2 & 1 & 18 & & & 1 & & & 14 & & & 6 & 3 & & 3 & & 12 & & 73 \\
\hline Parasesarma sp.3 & & & 6 & & & & & & & & & & & & & & & & & & & & & & 6 \\
\hline Sarmatium germaini & 7 & 1 & & 25 & 13 & 18 & & 1 & 1 & & & 2 & & & 2 & 23 & 44 & 30 & & & & 41 & 22 & 2 & 232 \\
\hline Scylla olivacea & & 1 & & & & & & & & & & & & & & & & & & & & & & & 1 \\
\hline Selatium brocki & & & & & & & & & & & & & & & & 1 & & & & & & & & & 1 \\
\hline Sesarmoides borneensis & & 5 & 12 & & & & 6 & 1 & 2 & & & 2 & & & 3 & 1 & 14 & 5 & 3 & & 2 & 7 & 39 & 5 & 107 \\
\hline Thalassina anomala & & & 1 & & & & & & & & & & & & & 1 & & & & & & 5 & 1 & & 8 \\
\hline Thalassina squamifera & & & & & & & & & & & & & & & & & & & & & & 3 & & & 3 \\
\hline Uca coarctata & 1 & 6 & & 9 & & 3 & & & 1 & 1 & & & & & & & 5 & & & & & & & & 26 \\
\hline Uca perplexa & & & & & & & & & & & & & & & & 1 & 63 & & & & & & & & 64 \\
\hline Uca sp. & 2 & & & & & & & & & & & & & & & & & 1 & & & & & & & 3 \\
\hline Uca triangularis & & & & 9 & & 3 & & & & & & & & & & & 4 & & & & & & & & 16 \\
\hline Utica borneensis & 1 & 1 & 2 & & & & & & & & & & & & & & & & & & & & & & 4 \\
\hline Varuna yui & & & & & & & & & & & & & & & & & & & 1 & & & & & & 1 \\
\hline Total species & 14 & 12 & 14 & 6 & 3 & 8 & 7 & 7 & 11 & 7 & 2 & 5 & 3 & 2 & 6 & 14 & 16 & 9 & 7 & 2 & 6 & 9 & 9 & 3 & 41 \\
\hline
\end{tabular}




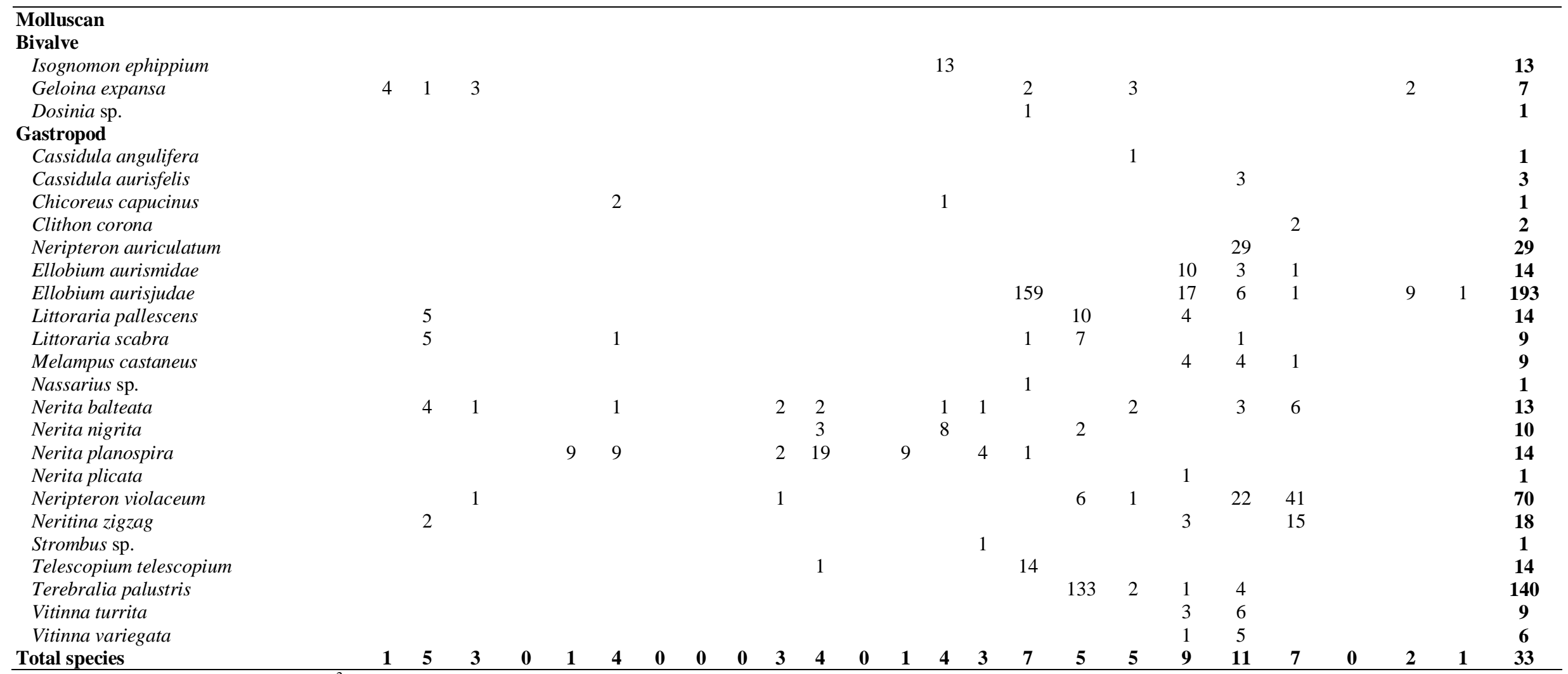

Note: Samples were collected from $25 \mathrm{~m}^{2}$ quadrat. $\mathrm{A}=10 \mathrm{~m}, \mathrm{~B}=250 \mathrm{~m}, \mathrm{C}=500 \mathrm{~m}$ distances perpendicular to the riverbank 
Table 4. Mean numbers of crustacean and mollusks found in the transect of $25 \mathrm{~m} 2$ in Mimika District, Papua, Indonesia

\begin{tabular}{lcccccc}
\hline \multicolumn{1}{c}{ Location } & $\mathbf{S}$ & $\mathbf{N}$ & $\mathbf{d}$ & $\mathbf{H}^{\prime}$ & $\mathbf{J}$ & $\mathbf{D}$ \\
\hline Crustacean & 24 & 472 & $2.46 \pm 0.07$ & $1.68 \pm 0.13$ & $0.65 \pm 0.07$ & $0.28 \pm 0.09$ \\
Kamora-1 & 8 & 154 & $1.16 \pm 0.02$ & $1.28 \pm 0.12$ & $0.77 \pm 0.02$ & $0.34 \pm 0.12$ \\
Kamora-2 & 12 & 174 & $1.80 \pm 0.07$ & $1.39 \pm 0.26$ & $0.66 \pm 0.07$ & $0.35 \pm 0.07$ \\
Tipuka-1 & 10 & 117 & $1.03 \pm 0.27$ & $0.92 \pm 0.72$ & $0.57 \pm 0.27$ & $0.55 \pm 0.34$ \\
Tipuka-2 & 7 & 79 & $0.80 \pm 0.04$ & $0.95 \pm 0.48$ & $0.79 \pm 0.04$ & $0.48 \pm 0.19$ \\
Ajkwa-1 & 24 & 729 & $2.19 \pm 0.12$ & $1.46 \pm 0.46$ & $0.57 \pm 0.12$ & $0.38 \pm 0.18$ \\
Ajkwa-2 & 10 & 45 & $1.54 \pm 0.04$ & $1.40 \pm 0.66$ & $0.94 \pm 0.04$ & $0.30 \pm 0.22$ \\
Minajerwi-1 & 12 & 318 & $1.35 \pm 0.16$ & $1.34 \pm 0.27$ & $0.77 \pm 0.16$ & $0.31 \pm 0.06$ \\
Minajerwi-2 & & & & & & \\
Mollusks & 9 & 32 & $1.39 \pm 0.66$ & $1.21 \pm 0.62$ & $0.86 \pm 0.12$ & $0.31 \pm 0.26$ \\
Kamora-1 & 5 & 23 & $0.80 \pm 0.15$ & $0.42 \pm 0.22$ & $0.57 \pm 0.15$ & $0.67 \pm 0.22$ \\
Kamora-2 & 0 & 0 & 0 & 0 & 0 & 0 \\
Tipuka-1 & 5 & 30 & $1.09 \pm 0.27$ & $0.62 \pm 0.55$ & $0.77 \pm 0.27$ & $0.48 \pm 0.17$ \\
Tipuka-2 & 7 & 54 & $0.64 \pm 0.67$ & $0.60 \pm 0.61$ & $0.64 \pm 0.12$ & $0.65 \pm 0.26$ \\
Ajkwa-1 & 13 & 346 & $1.26 \pm 0.37$ & $0.88 \pm 0.57$ & $0.53 \pm 0.37$ & $0.58 \pm 0.30$ \\
Ajkwa-2 & 15 & 197 & $1.93 \pm 0.13$ & $1.62 \pm 0.42$ & $0.73 \pm 0.13$ & $0.29 \pm 0.13$ \\
Minajerwi-1 & 2 & 12 & 0.42 & 0.16 & 0.68 & 0.85 \\
Minajerwi-2 & & & & -
\end{tabular}

Note: S: Total Species Number; N: Total Number of Individual; d: Species Richness (Margalef); H': Shannon Diversity Index; J': Pielou's Evenness; D: Shannon Dominancy

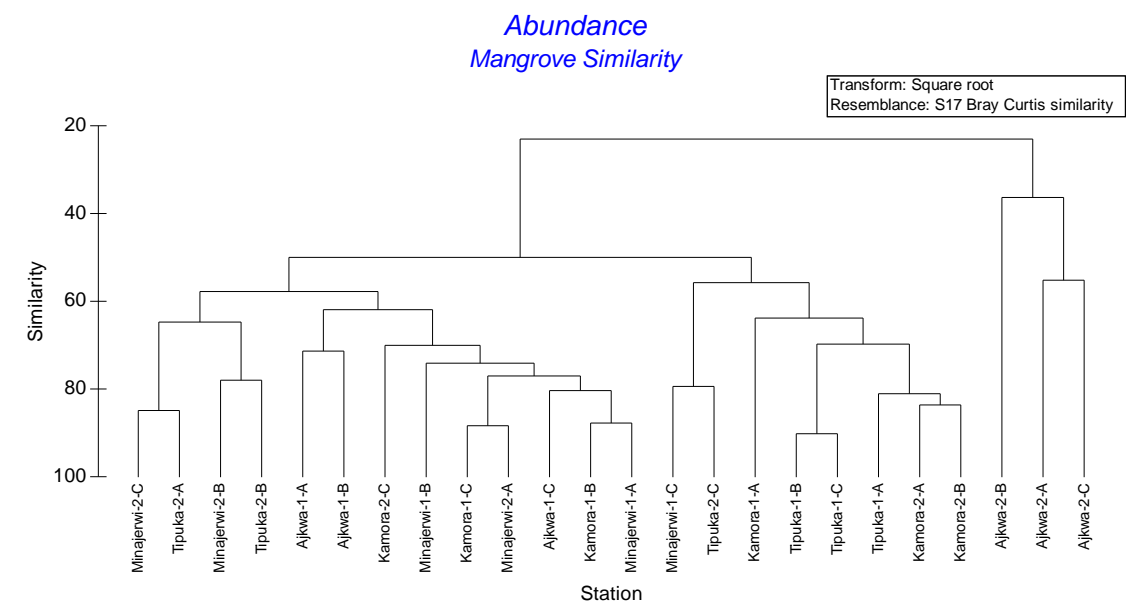

Figure 2. Dendrogram of Bray Curtis similarity of mangrove vegetation among sampling location in Mimika District, Papua, Indonesia. $\mathrm{A}=10 \mathrm{~m}, \mathrm{~B}=250 \mathrm{~m}, \mathrm{C}=500 \mathrm{~m}$ distances perpendicular to the riverbank

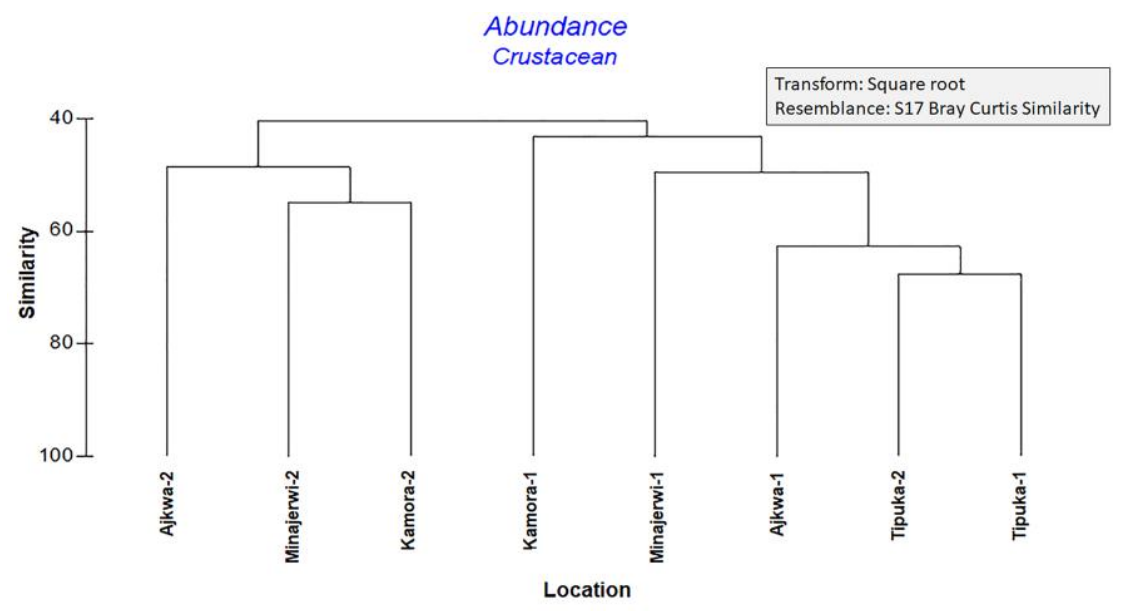

Figure 3. Dendrogram of Bray Curtis similarity of crustacean among sampling location in Mimika District, Papua, Indonesia 


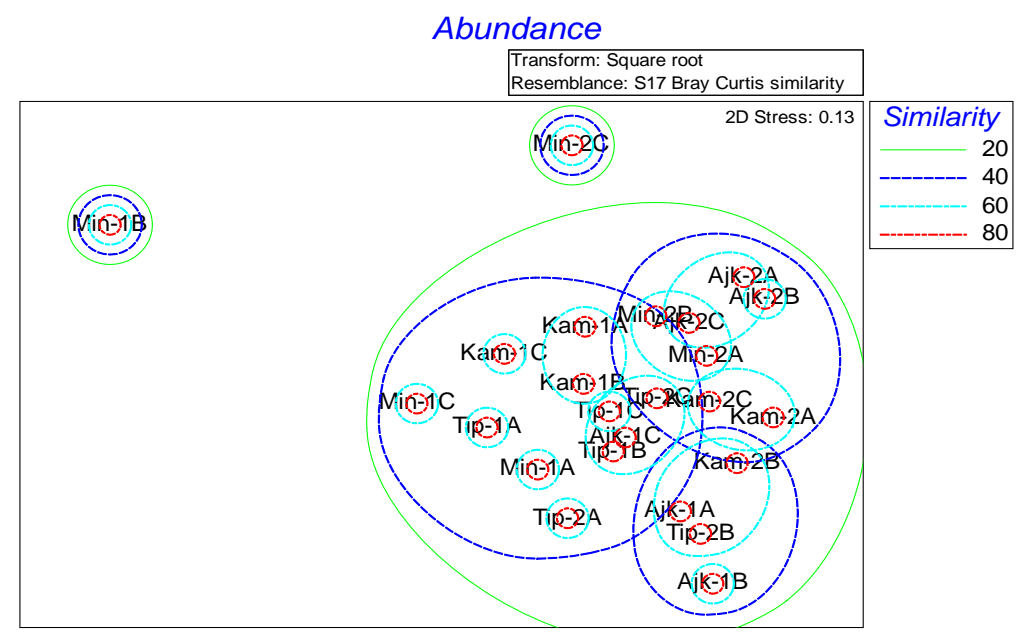

Figure 4. Bray Curtis similarity of crustacean based on plots in Mimika District, Papua, Indonesia. $A=0 \mathrm{~m}, \mathrm{~B}=250 \mathrm{~m}, \mathrm{C}=500 \mathrm{~m}$ distances perpendicular to the riverbank

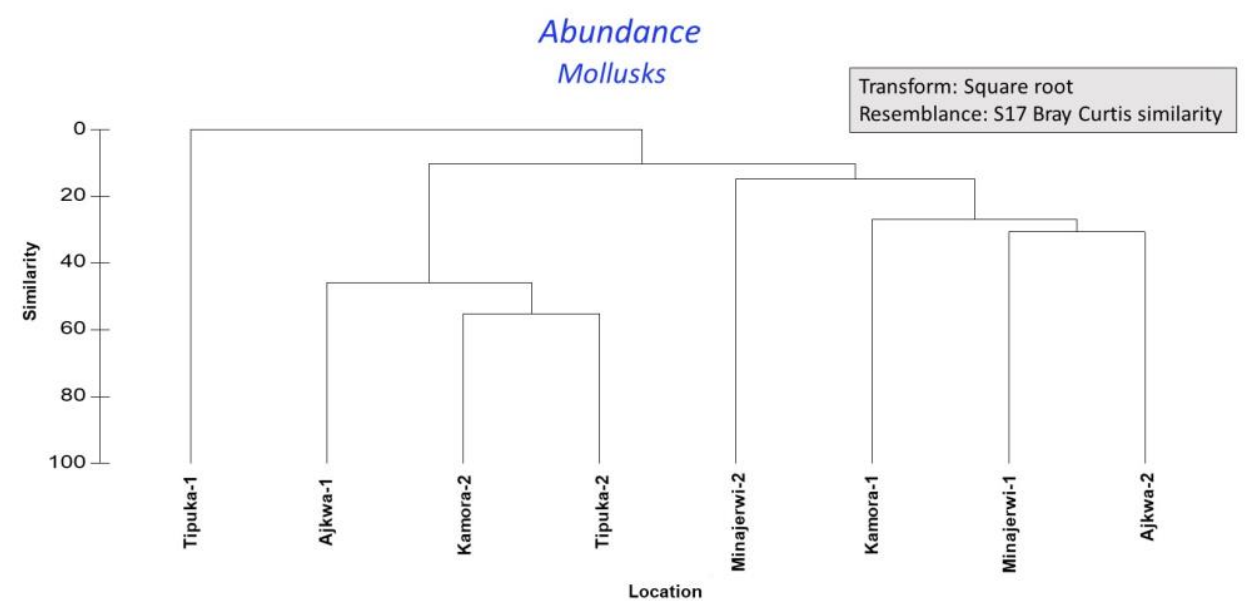

Figure 5. Dendrogram of Bray Curtis similarity of mollusk among sampling location in Mimika District, Papua, Indonesia

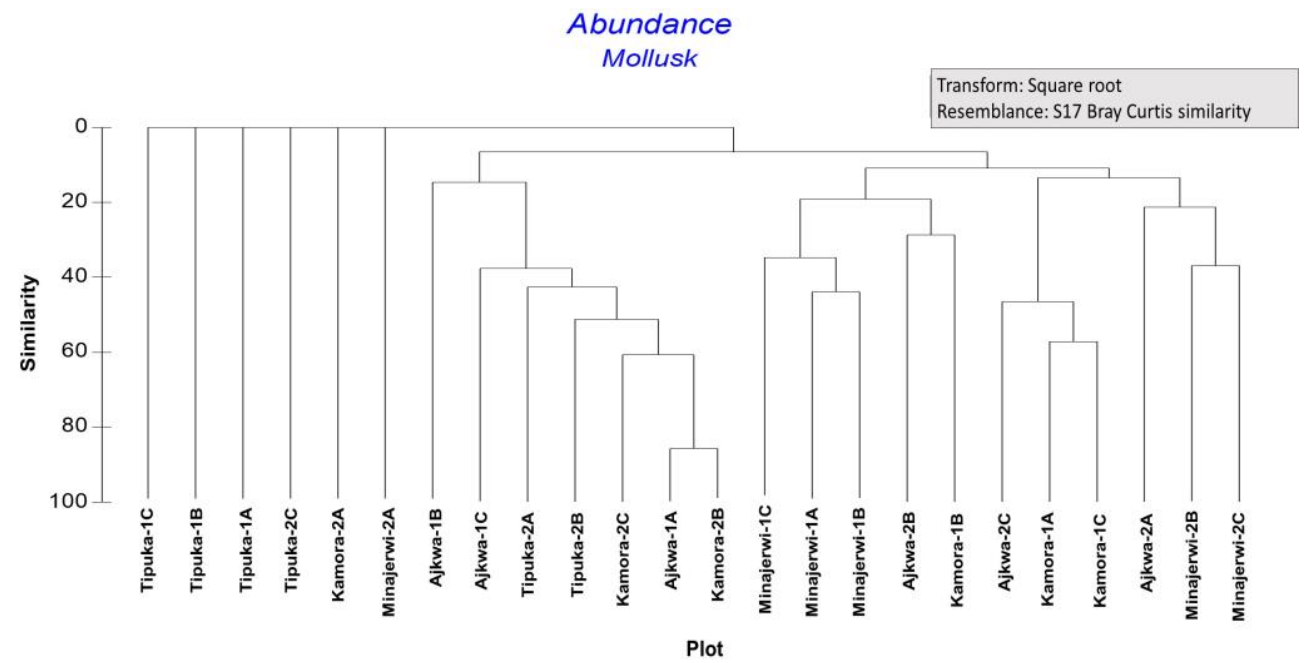

Figure 6. Dendrogram of Bray Curtis similarity of mollusk based on plots in Mimika District, Papua, Indonesia. A = 0m, B = 250m, C = $500 \mathrm{~m}$ distances perpendicular to the riverbank 
The highest Bray-Curtis similarity percentage for mollusks was found between Tipuka-2 and Kamora-2 (55.27\%). Other locations with high similarity were Tipuka-2 and Ajkwa-1 (48.63\%) and Kamora2 and Ajkwa$1(42.94 \%)$.

Based on plots, the mollusks can be clustered into four clusters. The first cluster comprised Tipuka-1A, Tipuka1B, Tipuka-1C, Tipuka-2C, Minajerwi-2A and Kamora2B, where mollusks were absent. Of the other three clusters, the first cluster comprised Ajkwa-1B, Ajkwa-1C, Tipuka-2A, Tipuka-2B, Kamora 2C, Ajkwa-1A and Kamora-2B, the second cluster comprised Minajerwi-1C, Minajerwi-1A, Minajerwi-1B, Ajkwa-2A, and Kamora-1B, and the third cluster comprised Ajkwa-2C, Kamora-1A, Kamora-1C, Ajkwa-2A, Minajerwi-2b, and Minajerwi-2C.

\section{Correlation of mollusks and crustaceans with mangrove association}

The results of the PCA used to determine the correlation between the abundance of crustacean and mollusk species with mangrove vegetation association are shown in Figure 7. There is a positive and strong correlation between $P$. foresti and the association of $A$. marina and $S$. alba., between $P$. cricotum and the mangrove association of $R$. apiculata and B. gymnorrhiza, and between $C$. amamaparense and the association of $B$. gymnorrhiza, $R$. apiculata, and $B$. parviflora. S. germaini had a quite close relationship with the association of $S$. alba and A. marina, Sesarmoides borneensis with the association of $R$. apiculata and B. parviflora, and $A$. euphrosyne with the association of $R$. apiculata and $B$. gymnorrhiza. For mollusks, strong correlations were found for T. palustris and E. aurisjudae with the association of $R$. apiculata and B. parviflora. Correlations were also found

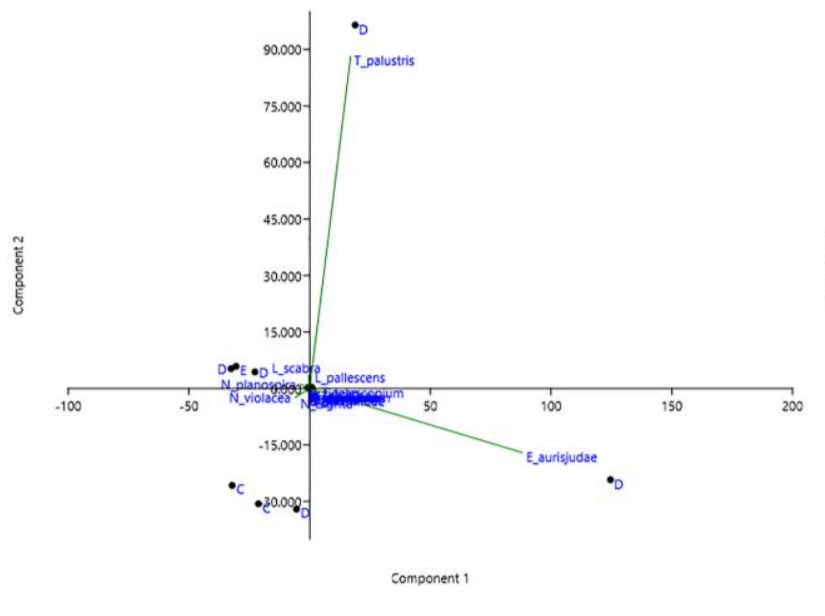

A for $N$. planospira and $N$. violacea with the association of $R$. apiculata and B. parviflora.

\section{Discussion}

A total of 41 crustacean species were found in this study, consisting of 37 crab species, 3 shrimp species, 1 hermit crab species, and 1 mud lobster species. A publication of the crustacean species of Mimika District by Rahayu and Setyadi (2009) revealed 103 species of crustaceans belonging to three infra orders (Anomura, Brachyura, and Thalassinidea) inhabiting the mangrove estuary environment. The number of crab species found in this study is higher compared with other mangrove areas, such as the 31 crab species found in the Sematan mangrove forest, Sarawak, Malaysia (Ashton et al. 2003 ${ }^{a}$ ), 13-40 crab species in India (Sakthivel and Fernando 2012; Mohanty et al. 2019), and 25 crab species on the Cameroon Atlantic Coast (Ngo-Massou et al. 2018).

The abundance of crustaceans in this study for $25 \mathrm{~m}^{-2}$ plots was $87 \pm 3.5$ individuals. The abundance is higher compared to the study by Ashton et al. $\left(2003^{\mathrm{a}}\right)$ in Malaysia, which found abundances of $16 \pm 5.9$ and $6.3 \pm 5.5 \mathrm{crabs}$, and in Thailand, with the abundance varying from 15 to 52 crabs (Ashton et al. 2003 ${ }^{\mathrm{b}}$ ). The differences between the results might have been due to the collection method, with Ashton et al. (2003 a and $2003^{\mathrm{b}}$ ) employing a time-based sampling method (15 minutes) in each $100 \mathrm{~m}^{2}$ mangrove forest. Meanwhile, this study in Mimika, Papua, was more labor-intensive as it collected crustaceans by excavating sediment with a shovel from $25 \mathrm{~m}^{2}$ plots until animals were no longer found. This method seems to be more effective and offers a greater chance of catching crabs hiding in burrows or under fallen trunks. A similar method was applied by Ngo-Masou et al. (2018), with a plot size of $4 \mathrm{~m}$ $\times 4 \mathrm{~m}$.

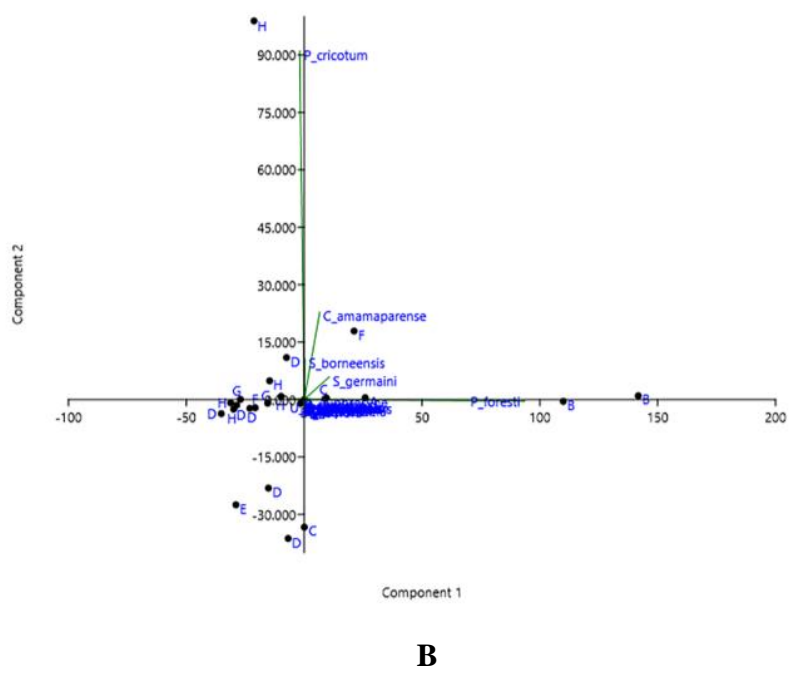

Figure 7. Principal Correlation Analysis of crustacean species (A) and mollusks species (B) with mangrove community types in Mimika District, Papua. A. Association of S. alba and A. marina, B. Association of A. marina, S. alba, B. parviflora and R. apiculata. C. Association of $R$. apiculata, B. gymnorrhiza and X. granatum. D. Association of $R$. apiculata and B. parviflora. E. Association of B. gymnorrhiza and $R$. apiculata; F. Association of B. gymnorrhiza, R. apiculata, B. parviflora, and C. schultzii, G. Association of R. apiculata and B. gymnorrhiza and C. schultzii. H. Association of R. apiculata and B. gymnorrhiza 


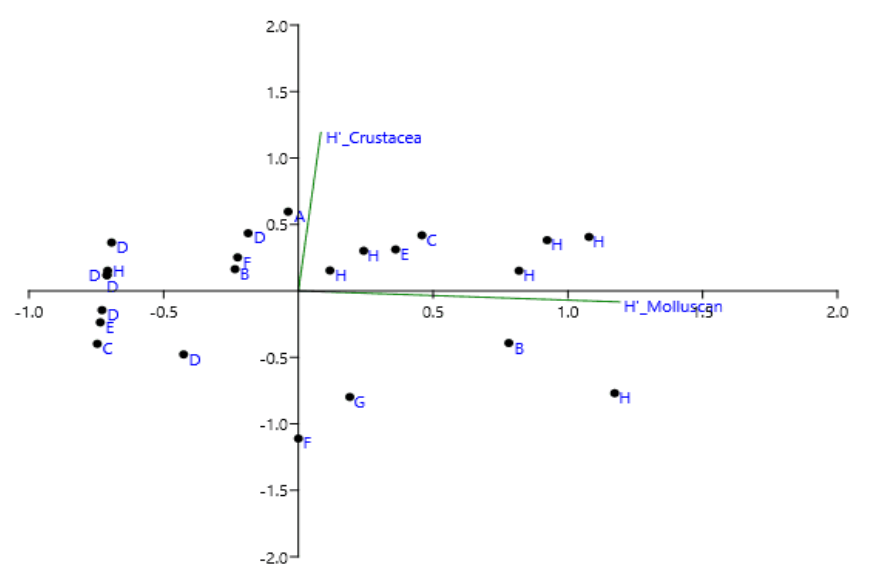

Figure 8. Principal Correlation Analysis of diversity of crustaceans and mollusks with mangrove community types in Mimika District, Papua. A. Association of $S$. alba and A. marina, B. Association of A. marina, S. alba, B. parviflora and R. apiculata. C. Association of $R$. apiculata, B. gymnorrhiza and X. granatum. D. Association of $R$. apiculata and B. parviflora. E. Association of B. gymnorrhiza and $R$. apiculata; F. Association of B. gymnorrhiza, R. apiculata, B. parviflora, and C. schultzii, G. Association of $R$. apiculata and B. gymnorrhiza and C. schultzii. H. Association of R. apiculata and B. gymnorrhiza

The most abundant and common crustacean species found in this study was $P$. indiarum, with a total of 785 individuals. This crab species had a very wide distribution as it was found in all sampling plots, except the sampling plot in which Nypa fruticans appeared. This crab takes shelter under fallen logs and tree trunks or burrows into the muddy bottom of shallow pools. The diet of Parasesarma spp. (formerly in the genus Perisesarma, Shahdadi and Schubart 2017), which is mangrove leaves, helps to trap energy in the mangrove ecosystem before it is carried away by the tide (Gillikin and Schubart 2004).

Another crab species with a wide distribution was $C$. amamaparense, with a total of 215 individuals found. This species was only absent in sampling plots with the association of $C$. schultzii and N. fruticans. Based on PCA analysis, this species has a strong correlation with the mangrove association of B. gymnorrhiza, R. Apiculata, and B. parviflora. The wide distribution of this species may be related to its dense coat of setae, which have a mud-like color and may serve as camouflage to avoid predators (Lee et al. 2013).

Species of crabs that were abundant but had less distribution were $P$. cricotum (280 individuals from 8 plots), S. germaini (232 individuals from 15 plots) and Sesarmoides borneensis (107 individuals from 15 plots). Based on PCA, $P$. cricotum has a very strong relationship with the mangrove association of $R$. Apiculata and $B$. gymnorrhiza, whereas $S$. germaini has a fairly close relationship with the association of $S$. alba and A. marina. The majority of plots where $S$. germaini were found were located in the seaward margin, with higher salinity and more frequent inundation. Several crustaceans discovered exclusively in the seaward margin of the mangrove at Ajkwa-2, which has a dominancy of S. alba and A. marina, were Clibanarius longitarsus, Ilyoplax dentatus, Mictyris $s p$., and Uca perplexa. It can be assumed that those species prefer to live in conditions of high salinity and with more frequent inundation.
The total number of mollusks found in this study was 32 species, comprising 3 species of bivalves and 29 species of gastropods. Previous publications by Setyadi et al. (Setyadi et al. 2009) recorded 17 species of gastropods and 6 species of bivalve in Mimika District. In Indonesia, at least 48 species of gastropods and 9 species of bivalves have been recorded (Hanum et al. 2014). As a comparison, a study in Aceh Besar and Banda Aceh Besar in Sumatra, Indonesia, recorded 14 species of gastropods and 5 species of bivalves (Dewiyanti and Sofyatuddin 2013), while 44 species of mollusk were recorded in Sematan mangrove forest in Malaysia (Ashton et al. 2003 ${ }^{\mathrm{a}}$ ), and 14 and 19 species of gastropods and 10 and 3 species of bivalves were recorded, respectively, in Gujarat and Paradeep, India (Thivakaran and Sawale 2016; Yadav et al. 2018). The abundance of mollusks in this study was $1.2 \pm 1.9 \mathrm{~m}^{-2}$, which is much lower than the 371 individuals $\mathrm{m}^{-2}$ of gastropods and 28 individuals $\mathrm{m}^{-2}$ of bivalves found in Aceh (Dewiyanti and Sofyatuddin 2013), the 64 to 1518 individuals $\mathrm{m}^{-2}$ of gastropods and 40 to 833 individuals $\mathrm{m}^{-2}$ of bivalves in Gujarat (Thivakaran and Sawale 2016), and the $25 \pm 25$ and $17 \pm 25$ individuals $\mathrm{m}^{-2}$ of mollusks in Sematan, Malaysia (Ashton et al. 2003 ${ }^{\mathrm{a}}$ ). The low abundance may be due to the activity of local fishermen as clams and gastropods are the main source of protein for indigenous people living in the coastal areas of Mimika.

Strong correlations of $T$. palustris and E. aurisjudae were found with the association of $R$. apiculata and $B$. parviflora (Figure 2). Those two species might have a dependence on the detritus from the litterfall of $B$. parviflora since $R$. apiculata was found in all locations. This conclusion is consistent with the study by Fratini et al. (2001), which found that large numbers of $T$. palustris consume all mangrove species and feed either in clusters or individually on fallen mangrove leaf litter.

Figure 8 shows the correlations of the Shannon diversity indices $\left(\mathrm{H}^{\prime}\right)$ for crustaceans and mollusks with the ecosystem types in the Mimika District. The graph shows 
that the mangrove community with the crustacean highest diversity was the association of $S$. alba and A. marina locations with a high tidal zone and more frequent inundation by seawater. The highest Shannon diversity index was at Ajkwa-2B (1.915), which was associated with S. alba and A. marina (A). This is higher than that found in the studies in Malaysia and Thailand, which had a highest Shannon diversity index of 1.5 (Ashton et al. 2003 ${ }^{\mathrm{b}}$ ), or in South Sulawesi, with a highest Shannon diversity index of 0.893 (Hamid and Wardiatno 2018). However, the diversity index is lower than was found for the North Andaman Sea (Kumaralingam et al. 2013), which was 3.38, in Cameroon, which was 3.3 (Ngo-Massou 2018), and in Thailand, which was 2.12 (Macintosh et al. 2002). Salinity may be the contributing factor in the high diversity of crustaceans, which is consistent with another study (Ashton et al. $2003^{\mathrm{a}}$ ).

The diversity of mollusks showed a correlation with the association of $R$. apiculata and B. gymnorrhiza. The highest Shannon diversity index was at Minajerwi 1B (1.941), which featured the association of $R$. apiculata and B. gymnorrhiza $(\mathrm{H})$. The association of $R$. apiculata and $B$. gymnorrhiza was found mostly in the upper estuary. It seems that mollusk diversity depends on the species composition due to the different food habits of different aquatic faunas. Gastropod species, such as T. palustris, are known as major consumers of mangrove leaf litter (Nagelkerken et al. 2008), but microalgae may have contributed towards the gastropod diet (Raw et al. 2017). Meanwhile, bivalves are filter feeders, primarily consuming phytoplankton. Therefore, the mollusk diversities in the mangrove communities are likely to be influenced by physical conditions, such as inundation, salinity, the community structure of the mangrove vegetation, and mangrove detritus (Kabir et al. 2014).

In conclusion, the diversity of crustaceans and mollusk macrofauna in the Mimika District of Papua, Indonesia, is among the highest in the world. One of the main reasons is the vast and undisturbed mangrove forest in Papua, which covers an area of more than 1.4 million hectares, making it one of the largest mangrove forests in the world. However, limited publications have been found on its mangrove ecology and the interaction between the mangrove forest community and mangrove invertebrates. Since mangrove invertebrates play a significant role in decomposing mangrove litter-fall as a source of organic matter for adjacent coastal waters, a better understanding of mangrove invertebrate ecology, particularly in terms of crustaceans and mollusks, will help promote conservation efforts for this pristine mangrove ecosystem.

\section{ACKNOWLEDGEMENTS}

We would like to thank PT Freeport Indonesia for the support and facilitation in conducting this study and to the Department of Marine Science, Faculty of Fishery and Marine Science, Universitas Diponegoro for their involvement in the field data collection. Thanks also to Dr. Rick Cardwell for helping to review the work and provide valuable inputs. The authors declare no competing interests.

\section{REFERENCES}

Ashton EC, Hogarth PJ, Macintosh DJ. 2003a . A baseline study of the diversity and community ecology of crab and molluscans macrofauna in the Sematan Mangrove Forest, Sarawak, Malaysia. J Trop Ecol 19 (2): 127-142. DOI:10.1017/S0266467403003158

Ashton EC, Hogarth PJ, Macintosh DJ. 2003 ${ }^{\mathrm{b}}$. A comparison of brachyuran crab community structure at four mangrove locations under different management systems along the Melaka StraitsAndaman Sea Coast of Malaysia and Thailand. Estuaries 26 (6): 1461-1471. DOI:10.1007/BF02803654

Aslan A, Rahman AF, Robesond SM. 2018. Investigating the use of Alos Prism data in detecting mangrove succession through canopy height estimation. Ecol Indic 87: 136-143. DOI: 10.1016/j.ecolind.2017.12.008

Cantera J, Arnaud PM, Thomassin BA. 1983. Biogeographic and ecological remarks on molluscan distribution in mangrove biotopes. 1. Gastropod. J Molluscan Stud 49: 10-26. DOI: 10.1.1.997.4429\&rep=rep1\&type=pdf

Colpo KD, Chacur MM, Guimarães FJ. 2011. Subtropical Brazilian mangroves as a refuge of crab (Decapoda: Brachyura) diversity. Biodivers Conserv 20: 3239-3250. DOI: 10.1007/s10531-011-0125-x

Dewiyanti I, Sofyatuddin K. 2013. Diversity of Gastropods and Bivalves in mangrove ecosystem rehabilitation areas in Aceh Besar and Banda Aceh districts, Indonesia. ACCL Bioflux 5 (2): 55-59. DOI: 10.1.1.1056.5735\&rep=rep1\&type $=$ pdf

El-Regal MAA, Ibrahim NK. 2014. Role of mangroves as a nursery ground for juvenile reef fishes in the southern Egyptian Red Sea. Egypt J Aquat Res 40 (1): 71-78. DOI: 10.1016/j.ejar.2014.01.001

Fratini S, Cannicci S, Vannini M. 2001. Feeding clusters and olfaction in the mangrove snail (Linnaeus) (Potamididae: Gastropoda). J Exp Mar Biol Ecol 261: 173-183. DOI: 10.1016/S0022-0981(01)00273-8

Gillikin DP, Schubart CD. 2004. Ecology and systematics of mangrove crabs of the genus Perisesarma (Crustacea: Brachyura: Sesarmidae) from East Africa. Zool J Linn Soc 141 (3): 435-445. DOI: 10.1111/j.1096-3642.2004.00125.x

Hamid A, Wardiatno Y. 2018. Diversity of decapod crustaceans in Lasongko Bay, Southeast Sulawesi, Indonesia. Biodivers J 9 (3): 303 311. DOI: 10.31396/Biodiv.Jour.2018.9.3.303.311

Hanum IF, Latiff A, Hakeem KR, Ozturk M. 2014. Mangrove Ecosystems of Asia: Status, Challenges and Management Strategies. Springer, Germany.

Hogarth PJ. 2015. The Biology of Mangroves and Seagrasses. Oxford University Press, United Kingdom.

Kabir M, Abolfathi M, Hajimoradloo A, Zahedi S, Kathiresan K. 2014. Effect of mangroves on distribution, diversity and abundance of molluscs in mangrove ecosystem: A review. ACCL Bioflux 7 (4): 286-300.

Kasim F, Kadim MK, Nursinar S, Lamalango A. 2018. Comparison of true mangrove stands in Dudepo and Ponelo Islands, North Gorontalo District, Indonesia. Biodiversitas 20 (1): 259-266. DOI: 10.13057/biodiv/d200142

Krebb CJ. 1989. Ecological Methodology. Harpercollins College Div, New York.

Kumaralingam S, Sivaperuman C, Raghunathan C. 2013. Diversity and community structure of brachyuran crabs in North Andaman. In: Venkataraman K, Sivaperuman C, Raghunathan C (eds). Ecology and Conservation of Tropical Marine Faunal Communities. Springer, Germany.

Lee BY, $\mathrm{Ng} \mathrm{NK}, \mathrm{Ng}$ PKL. 2013. On the identity of Clistocoeloma balansae A. Milne-Edwards, 1873, and C. tectum (Rathbun, 1914), with description of a new species from the West Pacific (Crustacea: Decapoda: Sesarmidae). Zootaxa 3641 (4): 420-432. DOI: 10.11646/zootaxa.3641.4.8

Macintosh DJ, Ashton EC, Havanon S. 2002. Mangrove rehabilitation and intertidal biodiversity: A study in the ranong mangrove ecosystem, Thailand. Estuar Coast Shelf Sci 55: 331-345. DOI: 10.1006/ecss.2001.0896

Mohanty B, Nayak A, Dash B, Rout SS, Kumar BC, Patnaik L, Roy MKD, Raman A, Raut D. 2019. Biodiversity and ecological 
considerations of brachyuran crabs (Crustacea: Decapoda) from Devi estuary-mangrove region on the east coast of India. Reg Stud Mar Sci 32: 100865. DOI: $10.1016 /$ j.rsma.2019.100865

Morton B. 1983. Mangrove bivalves. In: Wilbur KW (eds). The Mollusca, Vol. 6. Ecology. Academic Press, New York

Nagelkerken I, Blaber SJM, Bouillon S, Green P, Haywood M, Kirton LG, Meynecke JO, Pawlik J, Penrose HM. 2008. The habitat function of mangroves for terrestrial and marine fauna: A review. Aquat Bot 89: 155-185. DOI: 10.1016/j.aquabot.2007.12.007

Ngo-Massou VM, Din N, Kenne M, Dogmo AB. 2018. Brachyuran crab diversity and abundance patterns in the mangroves of Cameroon. Reg Stud Mar Sci 24: 324-335. DOI: 10.1016/j.rsma.2018.09.010

PT Puri Fajar Mandiri (2002). Discharge Measurement at Rivers in the Vicinity of the COW Area of PTFI, June - August 2001. PT. Puri Fajar Mandiri, Engineering dan Business Consultants, Jakarta. [Unpublished Report]

Rahayu DL, Setyadi G. 2009. Mangrove Estuary Crabs of Mimika Region Papua, Indonesia. PT Freeport Indonesia and Research Center for Oceanography - Indonesian Institute of Sciences, Indonesia.

Ravichandran S, Fredrick WS, Khan SA, Balasubramanian T. 2011. Diversity of mangrove crabs in South and South East Asia. J Oceanogr Mar Environ Syst 1 (1): 01-07.

Raw JL, Perissinotto R, Miranda NAF, Peer N. 2017. Feeding dynamics of Terebralia palustris (Gastropoda: Potamididae) from a subtropical mangrove ecosystem. Molluscan Res 37 (4): 258-267. DOI 10.1080/13235818.2017.1323370

Sadono RD, Soeprijadi A, Susanto PYAP, Wirabuana J, Matatula. 2020 Short communication: Species composition and growth performance of mangrove forest at the coast of Tanah Merah, East Nusa Tenggara, Indonesia. Biodiversitas 21 (12): 5800-5804. DOI $10.13057 /$ biodiv/d211242
Sakthivel K, Fernando A. 2012. Brachyuran crabs diversity in Mudasal Odai and Nagapattinam coast of south east India. Arthropods 1 (4): 136-143. DOI: 10.1.1.1040.4925\&rep=rep1\&type=pdf

Setyadi G, Kastoro WW, Rahayu DL, Haris A, Dwiono SAP, Kailola P. 2009. Biota Aquatic of Mimika Waters, Papua. PT Freeport Indonesia and Research Center for Oceanography - Indonesian Institute of Sciences, Indonesia. [Indonesian]

Setyadi G, Pribadi R, Wijayanti DP, Sugianto DN. 2020. Mangrove diversity and community structure of Mimika District, Papua, Indonesia. Biodiversitas 2 (8): 3562-3570. DOI: $0.13057 /$ biodiv/d220857

Shahdadi A, Schubart CD. 2017. Taxonomic review of Perisesarma (Decapoda: Brachyura: Sesarmidae) and closely related genera based on morphology and molecular phylogenetics: New classification, two new genera and the questionable phylogenetic value of the epibranchial tooth. Zool Stud Linn Soc 20: 1-32. DOI: 10.1093/zoolinnean/zlx032

Tan CGS, Ng PKL. 1994. An annotated checklist of mangrove brachyuran crabs from Malaysia and Singapore. Hydrobiologia 285: 75-84. DOI: 10.1007/BF00005655

Thivakaran GA, Sawale AK. 2016. Mangrove macrofaunal diversity and community structure in Mundra and Kharo, Kachchh, Gujarat. Indian J Geo Mar Sci 45 (11): 1584-1592.

Yadav RPK, Malla D, Dash G, Bhoi S, Patro, Mohapatra A. 2018. Diversity of gastropods and bivalves in the mangrove ecosystem of Paradeep, east coast of India: a comparative study with other Indian mangrove ecosystems. Molluscan Res 39 (4): 325-332. DOI: 10.1080/13235818.2019.1644701

Zvonareva SS, Mekhova ES, Võ TH, Kantor YI. 2009. Checklist of bivalve molluscs in mangroves of Khánh Hòa Province, Vietnam. Molluscan Res 39: 296-312. DOI: 10.1080/13235818.2019.1638567 